\title{
Iron-Titanium Oxide Minerals in the Bjerkrem-Sogndal Massif, South-western Norway
}

\author{
by JEAN - CLAIR DUCHESNE \\ Institut de Géologie, Université de Liège, Belgique \\ WITH TWO PLATES
}

(Received 14 July 1970; in revised form 5 December 1970)

\begin{abstract}
Ilmenite and magnetite are investigated from the point of view of their distribution, microtexture, and chemical composition (major and minor elements) in the Bjerkrem-Sogndal massif (Egersund area, South-Rogaland, SW. Norway). This massif is an igneous layered synkinematic lopolith made up of cumulates of the anorthosite-mangerite suite. The lower part of the massif presents a rhythmic structure.

The microtextures of ilmenite result from simple exsolution of ilmenite-hematite solid solutions. Magnetite contains intergrowths of ilmenite formed by oxidation-exsolution of ulvöspinel-magnetite solid-solutions.

In the stratigraphic sequence, on a large scale, ilmenite appears first alone, and is then accompanied by magnetite; its hematite content decreases towards the top of the massif, while the titanium content of the magnetite increases. On the scale of the rhythms, similar trends but of lesser amplitude are also observed.

Evidence of deuteric readjustment of the orthomagmatic composition of the two oxides is provided (1) by the observation of microtextures at the contact between grains (zoning of primary ilmenite and rim of secondary ilmenite) (2) by the existence of differences in chemical composition between isolated grains and grains in contact, and (3) by the determination of the equilibrium temperature by means of the Buddington and Lindsley geothermometer.

Reconstitution of the $T-f_{\mathrm{O}_{\mathrm{z}}}$ orthomagmatic conditions in two particular levels of the massif shows that the reducing character of the magma increases during differentiation. The sudden changes in the oxide assemblage at the base of the rhythms reflect a sudden increase in the $f_{\mathrm{O}}$ of the magma. These increases, as shown by variation in $\mathrm{Cr}, \mathrm{Ni}$, and $\mathrm{Co}$, are due to recurrences of the basic character of the magma.

The variations of the minor elements $\mathrm{Mn}, \mathrm{V}, \mathrm{Ga}$, and $\mathrm{Zn}$ are interpreted in terms of the influence of the deuteric readjustment. It follows that the ratios $\mathrm{Mn} / \mathrm{Fe}^{\mathrm{g}+}, \mathrm{Ga} / \mathrm{Fe}^{\mathrm{s}+}$, and $\mathrm{Zn} /$ $\mathrm{Fe}^{\mathrm{s}+}$ increase and that the ratio $\mathrm{V} / \mathrm{Fe}^{3+}$ decreases in the magma in the course of differentiation. The distribution of $\mathrm{Mn}$ between ilmenite and magnetite is discussed.

Intermittent supplies of undifferentiated magma are proposed as the geological mechanism controlling the chemical recurrences associated with the rhythmic structure.
\end{abstract}

\section{INTRODUCTION}

THE Bjerkrem-Sogndal massif is part of the essentially anorthositic igneous South-Rogaland complex (SW. Norway). As was shown by P. Michot (1960a, $1964,1970)$, it is a synkinematic layered lopolith resulting from the gravity differentiation of the plagioclasic magma defined by Michot (1955). This process which occurred entirely in the deep catazone (Michot's mangeritic facies1951) gave birth to a series of cumulates starting from anorthosites at the base 
on the floor of the lopolith, passing to leuconorites, norites, monzonorites, then to mangerites, and finally at the top to quartz-mangerites (Fig. 1).

It was possible, owing to the existence of numerous index horizons, to establish a detailed 'stratigraphy' in the massif (Michot, 1964). Three main phases have been defined, which express the three main stages of the consolidation of the massif: (i) an essentially leuconoritic phase, by far the most voluminous one in the northern part of the massif, which also comprises anorthosites and norites; (ii) a monzonoritic phase; (iii) a mangeritic phase containing mangerites and quartz-mangerites; this constitutes the upper part of the stratiform structure and the central part of the lopolith.

The leuconoritic phase consists of a series of five rhythmic units (I to V) called major rhythms. The thickness of each rhythmic unit is of the order of several hundred metres. The standard lithologic sequence in a rhythm comprises a homogeneous anorthosite at the base changing to leuconorites in the upper part, then to a banded complex of leuconorites and norites at the top. Rhythms I and II are essentially anorthositic and leuconoritic, whereas rhythms III and IV, which are more complete, contain banded noritic horizons. Rhythm V, leuconoritic at its base and noritic in its upper part, gradually changes into rocks of the monzonoritic phase, which in perfect geometrical and lithological conformity constitute the transition to the mangerites and then to the quartzmangerites.

The rocks commonly show igneous lamination due to the arrangement of tabular feldspar and pyroxene crystals, parallel to the stratification. The feldspar, which is always the first mineral to crystallize, is commonly protoclastic. The oxides, ilmenite and magnetite, are the last with orthomagmatic crystallization: they are situated together in the interstices of the silicates tightly fitting their contours and the products of the protoclasis.

The evolution of the nature and proportion of the minerals constituting the rocks is shown on Fig. 2. The abscissa of these diagrams shows the chronology of the events which marked the consolidation of the massif, but has no absolute significance because phases and rhythms display considerable lateral variation in thickness (see Fig. 1).

It is worth mentioning that the two pyroxenes show an enrichment in $\mathrm{Fe}^{2+}$ upwards (Duchesne, 1969). Olivine, which is absent in the leuconoritic phase except in a horizon of leuconorite ('horizon de Svalestad'-Michot, 1960a) near the base of rhythm IV $\left(\mathrm{Fo}_{70}\right)$ appears initially in the monzonoritic phase. It rapidly grows richer in $\mathrm{Fe}^{2+}$ towards the top (from $\mathrm{Fo}_{50}$ to $\mathrm{Fo}_{6}$ ). Clinopyroxenebearing rocks contain a fluorapatite $(c / a=0.734)$ the amount of which reaches a maximum in the monzonoritic phase. Ilmenite is present in all the rocks of the massif; magnetite is absent from rhythm I and II, from the base of III and the lower part of IV, except in the level of olivine leuconorite previously mentioned. Ilmenite is the most abundant of the oxides. The two oxides display important variations in chemical composition on the scale of the massif and 


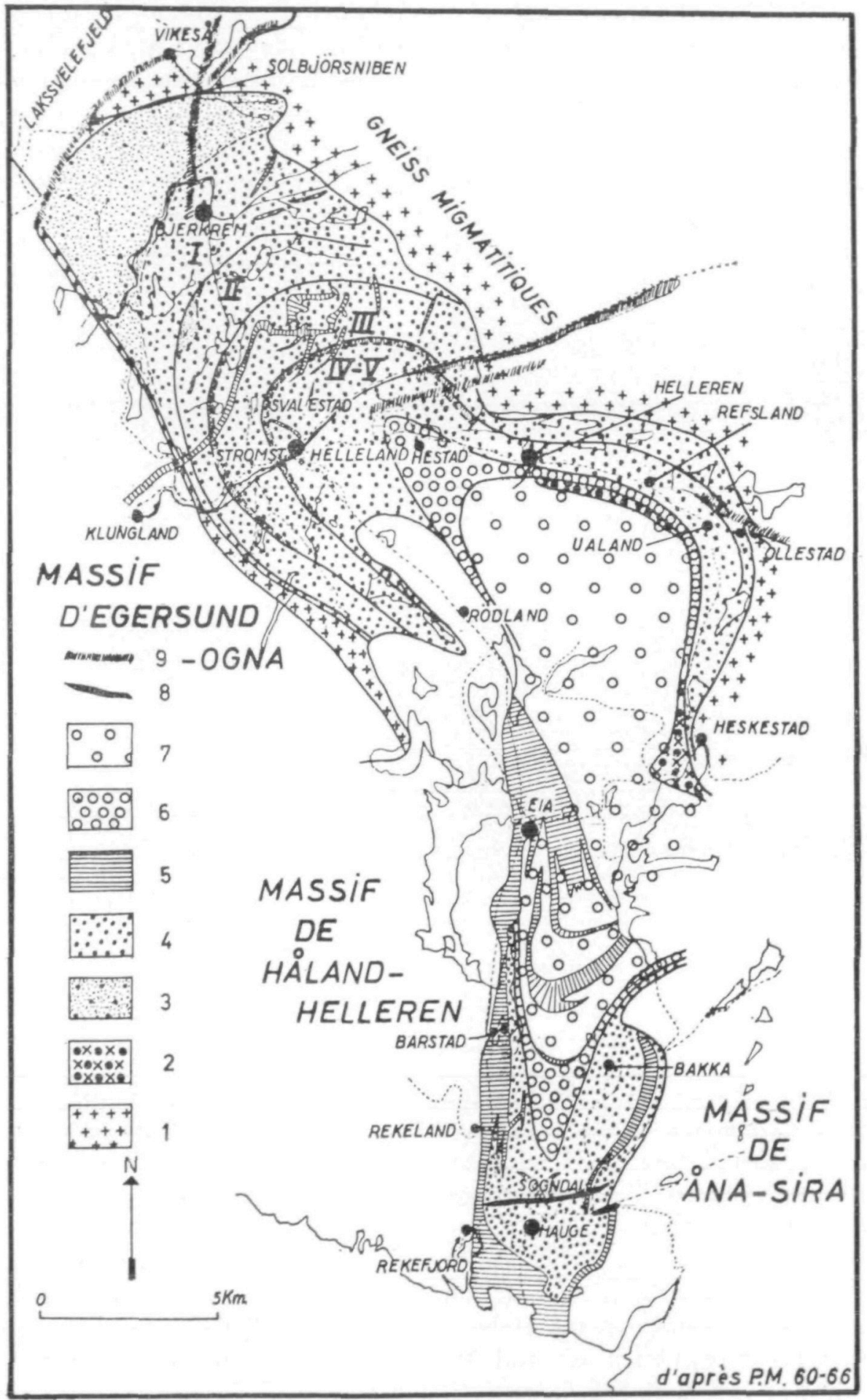

FIG. 1. The Bjerkrem-Sogndal massif (after P. Michot-1960a). 1. Migmatitic gneiss of the envelope; 2. Xenolithic septum; 3. Anorthosites; 4. Leuconorites and norites of the leuconoritic phase (divided in rhythms $I$ to V); 5 . Eia-Rekefjord intrusion and related dykes, essentially monzonoritic; 6 . Monzonorites and mangerites; 7. Quartz-mangerites; 8. Quartz-leucomangerites; 9. Faults. 
also within the rhythms. Details of these variations are given in the present paper. Red-brown biotite and amphibole of deuteric origin are occasionally associated with the oxides. Globules of sulphides (pyrrhotite and/or pyrite) are accessory constituents of all the rocks.

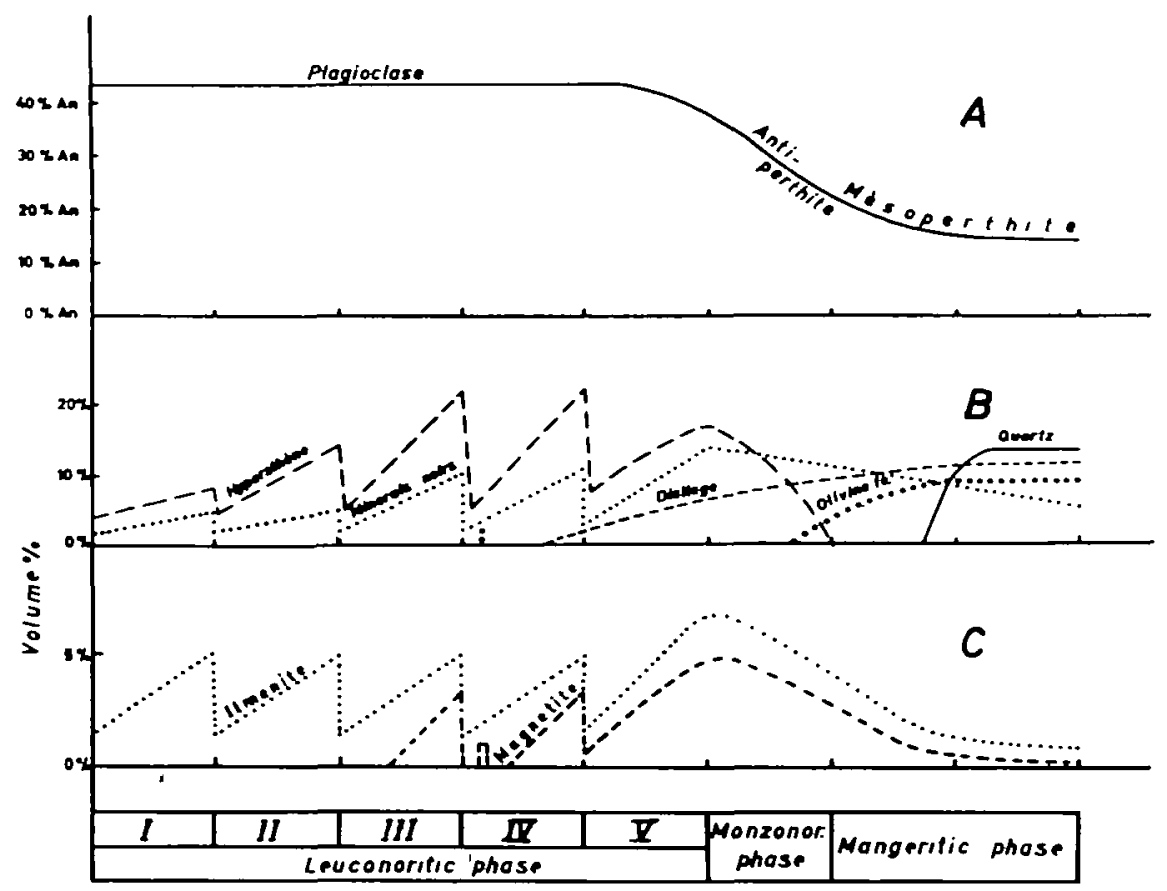

FIG. 2. A. (from P. Michot-1964, fig. 4) Variation of the anorthite content of the (unzoned) plagioclase. In the mesoperthites the value plotted refers to the An content of the exsolved lamellae of plagioclase. The potassium feldspar is present as independent grains in the monzonoritic phase. B. (from P. Michot-1964, fig. 4) Schematic variation in content of dark minerals ('hypersthène', 'diallage', and 'minerais noirs' standing for orthopyroxene, clinopyroxene, and oxide minerals respectively). c. Schematic variation of the ilmenite and magnetite content.

\section{METHODS OF STUDY}

The samples selected for chemical analysis were collected in the field by the author on the basis of P. Michot's stratigraphy. Ilmenite and magnetite were isolated after crushing and separation by means of the Frantz Isodynamic Separator and dense liquids (bromoform and heated Clerici solution) (Duchesne, 1966, 1969). Chemical analyses (Duchesne, 1969) were performed (i) by X-ray fluorescence for total $\mathrm{Fe}, \mathrm{Ti}$ (after fusion in borax) and for $\mathrm{Mn}, \mathrm{Zn}, \mathrm{Al}, \mathrm{Si}$, $\mathrm{Ca}$, and $\mathrm{S}$ (on pressed powdered samples); (ii) by $\mathrm{UV}$ emission spectrography for $\mathrm{Mg}, \mathrm{Cr}, \mathrm{V}, \mathrm{Ni}, \mathrm{Co}$, and $\mathrm{Ga}$; (iii) by titration with $\mathrm{K}_{2} \mathrm{Cr}_{2} \mathrm{O}_{7}$ for $\mathrm{Fe}^{2+}$. A few specimens were investigated with the electron-probe analyser following the method of Sweatman \& Long (1969). 
Complete analyses are given in Table 1 and are recalculated in terms of $\mathrm{RO}, \mathrm{R}_{2} \mathrm{O}_{3}$, and $\mathrm{TO}_{2}$. Temperature and oxygen fugacity according to the Buddington \& Lindsley (1964) geothermometer-oxygen barometer, are also reported.

\section{THE MICROTEXTURES OF THE OXIDES}

Detailed description and mode of formation of the microtextures of ilmenite and magnetite are given in Duchesne (1970b). The main characteristics may be briefly summarized here.

Ilmenite. Chemical composition of ilmenites (Fig. 3) is expressed as a first approximation in terms of ilmenite $\left(\mathrm{RTO}_{3}\right)$ and hematite $\left(\mathrm{R}_{2} \mathrm{O}_{3}\right)$ which are well known to form an extensive solid solution at high temperature (Carmichael, 1961). Under the microscope ilmenite either is homogeneous (when the Hem content is lower than $7 \mathrm{~mol}$ per cent) or contains lenses of hematite (when the Hem content exceeds 7 to 9 mol per cent); it is then called hemo-ilmenite. Since the abundance and size of the hematite lenses vary with the Hem content, it is possible to determine approximately the Hem content by means of the microscope (Duchesne, 1970b).

Magnetite. Chemical data (Fig. 3) clearly show that ilmenite $\left(\mathrm{RTO}_{3}\right)$ and magnetite $\left(\mathrm{R}_{3} \mathrm{O}_{4}\right)$ account in the main for the composition of the magnetites studied. Magnetite contains intergrowths of ilmenite according to two extreme types of microtextures: (i) the cloth microtexture; (ii) the trellis microtexture. The cloth microtexture (Pl. 1, figs. A, B) (Ramdohr, 1953) is formed by exsolution of ulvöspinel in the $\{100\}$ planes of the host magnetite and then by subsequent oxidation of the exsolved ulvöspinel into $\{111\}$ microlamellar ilmenite. In the trellis microtexture (Pl. 1, fig. C) the $\{111\}$-ilmenite lamellae are distinctly thicker and form a network with regular meshes. Both types of microtexture can coexist in the same grain (PI. 1, figs. D, E, F) ${ }^{1}$. The ilmenite of the trellis is interpreted as being formed by oxidation (mainly at supersolvus temperature) of ulvöspinel dissolved in magnetite. Thus the initial magnetite appears to have been magnetite $\left(\mathrm{R}_{3} \mathrm{O}_{4}\right)$-ulvöspinel $\left(\mathrm{R}_{2} \mathrm{TO}_{4}\right)$ solid solution. With the decrease in Ti content, the magnetite tends to become homogeneous and its chemical composition approaches the point of composition $\mathrm{R}_{3} \mathrm{O}_{4}$. Exsolution of aluminous spinel (zinciferous pleonaste) is common in the $\{100\}$ planes of the magnetite (Pl. 1, figs. A, E). When spinel is present in the magnetite, the ilmenite lamellae of the trellis are dotted with spinel microcrystals. Such an ilmenite +spinel association is also found in rims of ilmenite at the contact between primary ilmenite and magnetite (Pl. 1, figs. G, H; Pl. 2, figs. A, B) (see below). Occasional ropes of spinel granules are present between grains of magnetite (Pl. 1, fig. E).

1 A similar coexistence of cloth and trellis microtextures was already described by Vincent $e$ al. (1957, p. 647 and fig. 9) and Vincent (1960, p. 1013 and plates 134-5) in the magnetites of the Skaergaard Intrusion. 


\section{ExPLANATION OF TABLE 1}

ND: not determined; - : not detected. Lower limit of detection: $\mathrm{Cr}_{2} \mathrm{O}_{2}: 100 \mathrm{ppm} ; \mathrm{V}_{3} \mathrm{O}_{3}: 30 \mathrm{ppm}$; Ni \& $\mathrm{Co:} 30 \mathrm{ppm} ; \mathrm{S}$ in ilmenite: 0.1 per cent; $S$ in magnetite: 0.05 per cent.

(1) $0 \equiv \mathrm{S}$ is subtracted from the total.

(2) Samples slightly weathered (oxidation); the Hem content is evaluated under the microscope by comparison with other hemo-ilmenites having similar sizes and densities of hematite lenses.

(3) Calculation of $\mathrm{Hem}^{*}$ and Usp takes account of $\mathrm{FeO}, \mathrm{Fe}_{2} \mathrm{O}_{2}$, and $\mathrm{TiO}_{2}$ only, in order to facilitate comparison with the results of Buddington \& Lindsley (1964).

(4) In these rocks some magnetite grains have a trellis microtexture with coarse ilmenite lamellae. These lamellae are likely to be partially eliminated in the course of mineralogical separation. Two separations by slightly different methods (Duchesne, 1969) give two values for Ti, between which the true Ti content is situated.

(5) Electron-probe microanalysis (average of two analyses using a defocused beam of grain Pl. 1, fig. B). Total Fe expressed as FeO; the total to 100 includes 4.4 per cent $O$, calculated on the basis of a $\mathrm{Fe}_{2} \mathrm{O}_{4}+\mathrm{FeTiO}_{3}$ composition.

\section{Rhythm I}

\section{LIST OF SAMPLES}

1. Pyroxene- and ilmenite-bearing anorthosite (64M6) Saglandsvatn.

2. do. (66189) NW. Bjerkrem.

3. do. (66190) ibid.

4. do. (6671) Klungland-Helleland road.

5. do. (64155) W. Bjerkrem.

6. Leuconorite (64101) E. Saglandsvatn.

7. do. (6672) Klungland-Helleland road.

8. do. (6405) ibid.

\section{Rhythm II}

9. Ilmenite-bearing anorthosite (64160) Ravnefjeld.

10. Leuconorite (6408) Klungland-Helleland road.

11. do. (6409) ibid.

\section{Rhythm II}

12. Pyroxene- and ilmenite-bearing anorthosite (66187) Mögedalsvatn.

13 \& 13a. Leuconorite (6434) Klungland-Helleland road.

$14 \& 14 a$. do. (6436) ibid. (Stromstad).

$15 \& 15 a$. do. (6437A) ibid.

16 \& 16a. Noritic layer (6437B) associated with 6437A.

$17 \& 17$ a. Melanocratic noritic layer (6450) W. Teksevatn.

18 \& 18a. do. (6452) ibid.

19 \& 19a. Leuconorite (6674) Klungland-Helleland road.

$20 \& 20 \mathrm{a}$. Norite $(6675)$ ibid.

21 \& 21a. Norite (6461b) N. Stromstad.

\section{Rhythm IV}

22. Pyroxene- and ilmenite-bearing anorthosite (64107) Bentjafjeld.

23 \& 23a. Olivine-bearing leuconorite (6423) Svalestad.

24. Leuconorite (6420b) Helleland.

25 \& 25a. Melanocratic layer (6444) S. Teksevatn.

26 \& 26a. Leuconorite (6442) S. Teksevatn.

$27 \&$ 27a. Norite (6443) ibid.

28 \& 28a. Banded leuconorite (6695) Ollestad.

29 \& 29a. Pyroxenite (66212) Bakka.

30 \& 30a. do. (7771-P. Michot's coll.) ibid.

31 \& 31a. Norite (6476) ibid.

\section{Rhythm V}

32 \& 32a. Leuconorite (66107) Refsland station.

33 \& 33a. Antiperthitic leuconorite (64131) Hestad-Helleren road.

34 \& 34a. do. (7767-P. Michot's coll.) E Slatten. 
35 \& 35a. do. (7704-P. Michot's coll.).

36 \& 36a. Antiperthitic norite (66102) Helleland-Hestad road.

$37 \& 37$ a. do. (6460) ibid.

38 \& 38a. do. (66103) ibid.

Monzonoritic and mangeritic phases

$39 \& 39$ a. Antiperthitic olivine-bearing norite (6458) Helleland-Hestad road.

$40 \& 40 \mathrm{a}$. Olivine bearing monzonorite (64132) Hestad-Helleren road.

$41 \& 41$ a. do. (6457) Helleland-Hestad road.

$42 \& 42 a$. do. (64136) Hestad-Helleland road.

$43 \&$ 43a. Oxide minerals-rich peridotite (6482) Örsland-Bakka.

44 \& 44a. Olivine-bearing mangeromonzonite (7700-P. Michot's coll.) Rössland.

45 \& 45a. Oxide minerals-rich olivine pyroxenite (66216) Orsland.

46 \& 46a. Olivine-bearing mangeromonzonitic layer associated with 66216 .

47 \& 47a. Olivine-bearing mangeromonzonite (64104) Helleland-Hestad road.

48 \& 48a. do (66209) Sláten.

49 \& 49a. do. (66253) Helleland-Hestad road.

50 \& 50a. do. (64137) ibid. (associated with 66253).

51 \& 51a. do. (64134) Hestad.

52 \& 52a. Olivine-bearing mangerite (6470) E Herveland.

53 \& 53a, b, c. do. (TII-P. Michot's coll.) Herveland.

$54 \& 54 a, b$. Olivine-bearing quartz mangerite (6687) Steine.

55 \& 55a, b. do. (66261) W. Orsland.

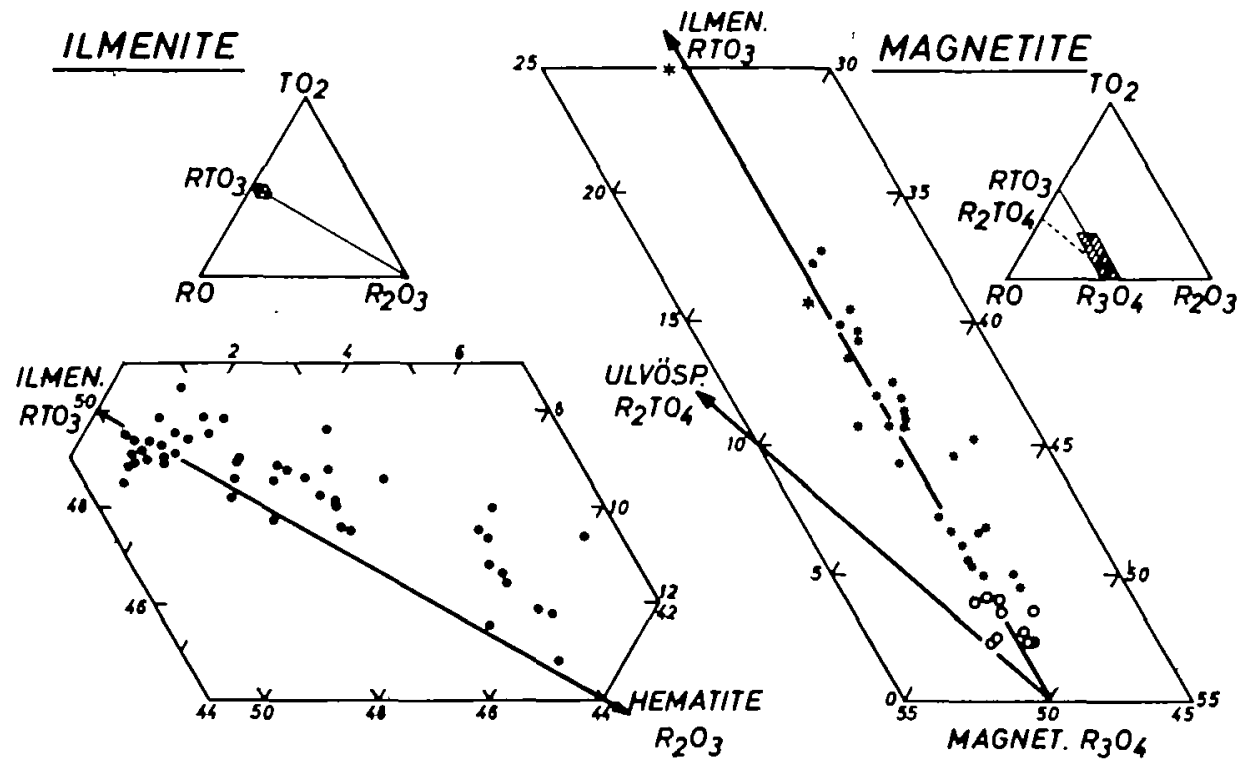

Fig. 3. Chemical analyses given in Table 1 plotted in terms of $\mathrm{RO}, \mathrm{R}_{2} \mathrm{O}_{\mathbf{2}}, \mathrm{TO}_{\mathbf{2}}$ (mole per cent). For the magnetite, three different symbols are used:

- cloth microtexture;

* trellis microtexture and intermediates between cloth and trellis microtextures;

o homogeneous magnetite. 


\section{EVOLUTION IN THE MASSIF}

The evolution in chemical composition of ilmenite and magnetite, as revealed by analysis of their $\mathrm{Hem}$ and $\mathrm{TiO}_{2}$ content respectively (Table 1), is represented in the variation diagrams (Figs. 4 and 5). These variations also correspond to variations in microtextures. Both aspects can be summarized in the following way:

(a) ilmenite shows on the scale of the massif a decrease of its Hem content: hemo-ilmenites ( 16 to $20 \mathrm{~mol}$ per cent Hem) occur in the lower part, ilmenites are homogeneous ( $2 \mathrm{~mol}$ per cent $\mathrm{Hem}$ ) at the top;

(b) magnetite becomes enriched in $\mathrm{Ti}$ towards the top; it presents first, a homogeneous ( $<2$ per cent $\mathrm{TiO}_{2}$ ), secondly, a trellis microtexture, thirdly, for the high $\mathrm{Ti}$ contents $\left(>9\right.$ per cent $\mathrm{TiO}_{2}$ ) trellis or cloth microtextures, the last one being, however, rather rare.

Therefore on a large scale, ilmenite (hemo-ilmenite) constitutes the only oxide of the rocks in the lowest part of the massif (see Fig. 2). Magnetite appears only subsequently and the two oxides form the Ti-poor, homogeneous magnetite + hemo-ilmenite assemblage which progressively yields to the Ti-rich magnetite +homogeneous ilmenite (poor in Hem) assemblage, characteristic of the rocks of the upper part of the massif.

On the scale of the rhythm, these major trends also repeat themselves: in rhythms III and IV, ilmenite is at first the only oxide present except for a brief occurrence of the two oxides in the olivine-bearing leuconorite near the base of rhythm IV (see Fig. 2). In these same rhythms and in rhythm $V$ the chemical compositions develop in directions identical with those defined on the larger scale, but their evolution is of lesser amplitude.

\section{Minor Elements}

Most of these show important variations on the scale of the massif as well as within the individual rhythmic units.

The Al content measured in magnetite by chemical analysis varies in close correlation with size and density of distribution of the exsolved spinel lenses, as observed under the microscope. It increases with $\mathrm{Ti}$ in rhythms III, IV, and $\mathrm{V}$, but from the top of rhythm $\mathrm{V}$ the relationship is reversed and $\mathrm{Al}$ diminishes and eventually disappears in the mangerites, where no spinel exsolution is ever detected.

In the two oxides, $\mathrm{Mn}$ increases with $\mathrm{Fe}^{2+}$ (Fig. 6), the ratio $\mathrm{Mn} / \mathrm{Ti}$ being constant in magnetite; $\mathrm{V}$ diminishes with $\mathrm{Fe}^{3+}$, the correlation between Hem and $\mathrm{V}$ being obvious in the ilmenites. Hence these two elements follow on all scales the same trends as the major elements for which they substitute.

In magnetite, $\mathrm{Ga}$ and $\mathrm{Zn}$ increase towards the top of the massif; a similar variation is apparent for $\mathrm{Zn}$ on the rhythm scale. 


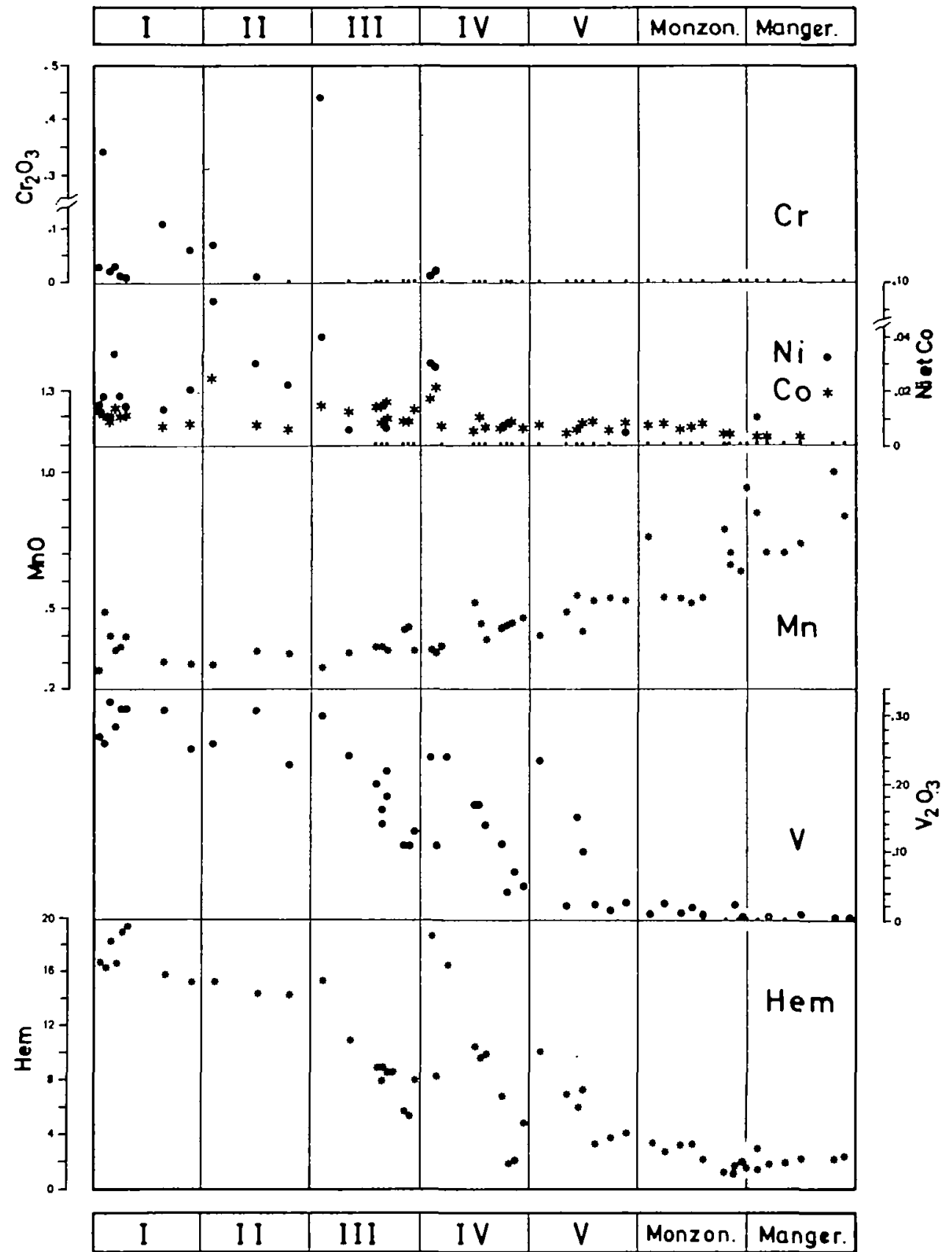

FIG. 4. Variation diagram of the ilmenite (see Table 1). Ni and $\mathrm{Co}$ are plotted on the same diagram using different symbols $\left(\mathrm{Ni}=\bullet ; \mathrm{Co}={ }^{*}\right)$. A smaller symbol on the zero line indicates a value below the detection limit. 


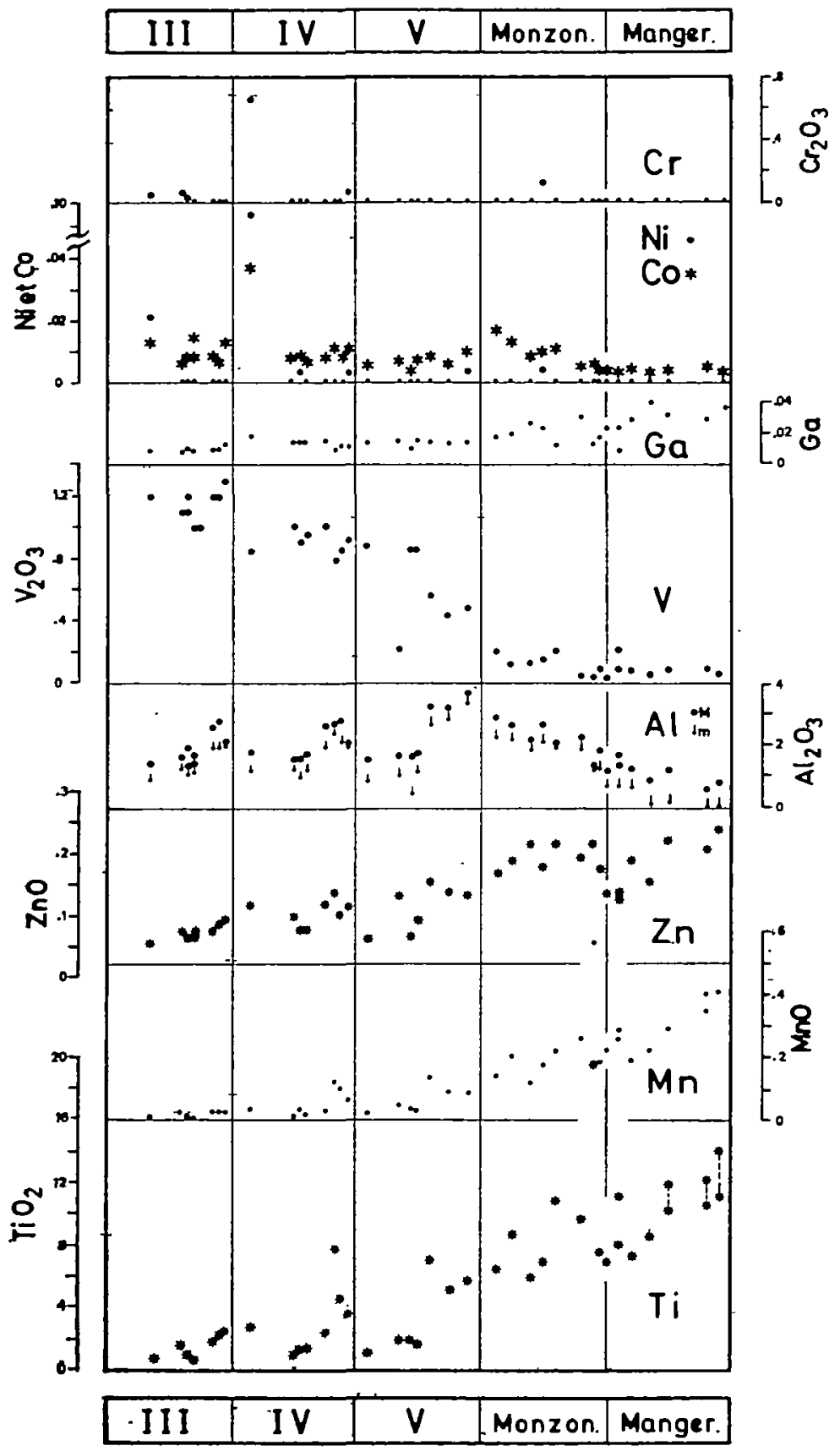

FIG. 5. Variation diagram of the magnetite (see Table 1). Same comments as in Fig. 4. Note that each Al-content is represented by two symbols corresponding to $\mathrm{Al}_{\mathrm{MI}}$ and $\mathrm{Al}_{\mathrm{m}}$ (see text). 
$\mathrm{Cr}, \mathrm{Ni}$, and $\mathrm{Co}$ are enriched at the base of the rhythms in ilmenite (rhythm I, II, III, IV) and magnetite (rhythm IV); they rapidly diminish towards the top of the rhythms and also, on the larger scale, towards the top of the massif. The Ni/Co ratio, $>1$ at the base, tends to values $<1$ towards the top of the rhythms and of the massif.
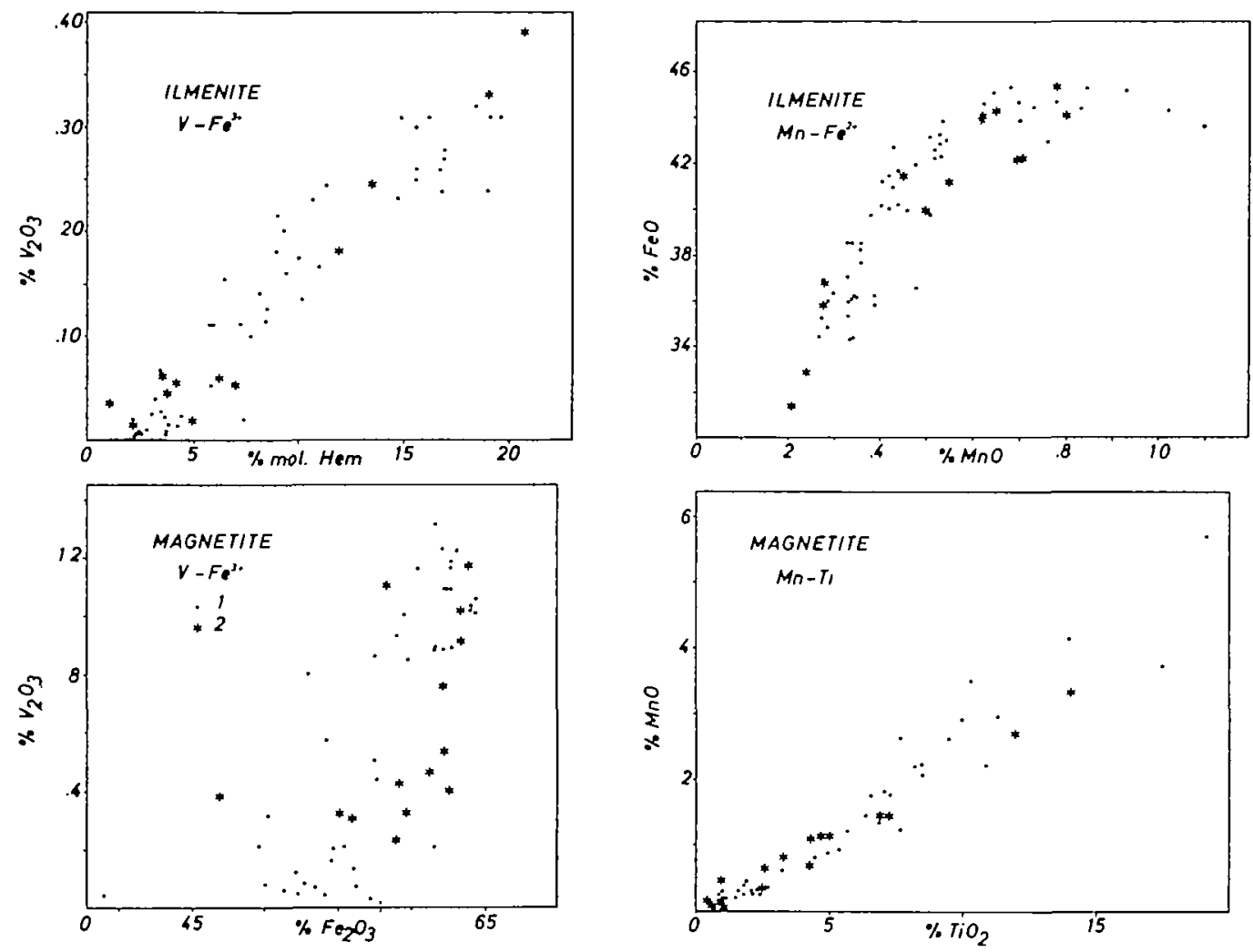

FIG. 6. Correlation between $\mathrm{Mn}$ and $\mathrm{Fe}^{3+}$ (or Ti) and between $\mathrm{V}$ and $\mathrm{Fe}^{3+}$ in magnetite and ilmenite.

- Bjerkrem-Sogndal massif (Table 1);

* Rogaland ores and Eia-Rekefjord intrusion (Duchesne, 1969).

$\mathrm{Si}, \mathrm{Ca}, \mathrm{Mg}$, and $\mathrm{S}$ will not be discussed because they are likely to be a result of contamination by other minerals. Although the same applies in part to $\mathrm{Al}$, it is nevertheless possible in the magnetites to extract a normative feldspar calculated on the basis of the amounts of $\mathrm{Si}$ and/or $\mathrm{Ca}$, and to obtain a minimum content $\mathrm{Al}_{\mathrm{m}}$, which is also plotted in the variation diagram; the 'true' $\mathrm{Al}$ content is situated between $\mathrm{Al}_{\mathrm{m}}$ and the measured value $\mathrm{Al}_{\mathrm{MI}}$. $\mathrm{Zn}$ in ilmenite is below the limit of detection of the method.

\section{EVIDENCE OF DEUTERIC READJUSTMENT OF THE OXIDES}

Although harmonious and regular, the observed chemical variations are not solely due to the chemical evolution of the magma in the course of differentiation. 
It transpires that a secondary phenomenon, intervening at the deuteric stage, superimposes its effects on those of magmatic differentiation by modifying the orthomagmatic composition of the oxides.

The interpretation of the phenomena observed at the contact between the grains of the two oxides and the use of experimental data lead to the explanation of the deuteric phenomena.

\section{A. Equilibrium temperatures of the oxides}

On the basis of Lindsley's experiments $(1962,1963)$ and of Buddington's petrological studies (Buddington et al., 1955), Buddington \& Lindsley (1964) have recommended the use of the coexisting magnetite and ilmenite to determine the temperature and oxygen fugacity prevailing at equilibrium between the two oxides. Application of these data to the Bjerkrem-Sogndal massif (Table 1) shows that the equilibrium temperatures increase towards the top of the intrusion and that a similar trend exists inside rhythms III, IV, and V. Therefore the equilibrium temperatures measured in this way cannot be orthomagmatic temperatures for these must necessarily decrease with differentiation, the sense of this being clearly defined by the structural and petrological facts. It is therefore legitimate to suspect a chemical evolution of the oxides posterior to the orthomagmatic stage.

\section{B. Phenomena at the contact of oxides}

At the contact between grains of magnetite and primary ilmenite, a rim of spinelliferous ilmenite in optical continuity with the neighbouring grain of primary ilmenite is observed (Pl. 1, figs. G, H; Pl. 2, figs. A, B). On the basis of microscopic study (Duchesne, 1970b) it has been shown that the rims and the ilmenite lamellae of the trellis are formed by the same mechanism, that is oxidation of the ulvöspinel contained in the magnetite.

When a grain of hemo-ilmenite is in contact with a grain of magnetite, the number and size of hematite lenses in a zone 20 to $80 \mu \mathrm{m}$ from the contact with the magnetite decrease progressively and they finally disappear (Pl. 2, figs. B, D). In the homogeneous ilmenite a similar gradient in the Hem content was demonstrated by electron-probe microanalysis (Duchesne, 1970b). This zoning never occurs at the contact with silicates or between two ilmenite grains. It reflects migrations in the ilmenite at supersolvus temperatures.

Rims and zoning are also common in the Fe-Ti ore-bodies of the Rogaland anorthosites as well as in other occurrences (see Duchesne, 1970b). Buddington \& Lindsley (1964) draw attention to 'granules . . . of ilmenite on the external borders of magnetite; . . . external granules exsolution', but they do not refer to zoning in the ilmenite.

These microtextures indicate that an exchange reaction ${ }^{1}$ took place between

1 As will be seen in the following section, isolated grains of ilmenite and magnetite do not show this phenomenon. 
the two oxides at the subsolidus stage, bringing about a decrease in the Hem content of the primary ilmenite and in the Ti content of the magnetite. In other words, primary ilmenite when in contact with magnetite can act as oxidant in the transformation of the ulvöspinel according to the reaction $\mathrm{Fe}_{2} \mathrm{TiO}_{4}+\mathrm{Fe}_{2} \mathrm{O}_{3}$ $\rightarrow \mathrm{FeTiO}_{3}+\mathrm{Fe}_{3} \mathrm{O}_{4}$, in which $\mathrm{Fe}_{2} \mathrm{TiO}_{4}$ and $\mathrm{Fe}_{2} \mathrm{O}_{3}$ are contained in the magnetite and in the primary ilmenite respectively. It is, however, difficult to assess the exact amount of secondary ilmenite thus produced, because this ilmenite is in optical continuity with the neighbouring grain of primary ilmenite. The spinel being distributed in a very heterogeneous way in the rim, the internal boundary to the grain of primary ilmenite is generally blurred (e.g. Pl. 1, fig. G). When there is no spinel in the magnetite, for example in the mangeritic phase, only an irregular boundary is visible in place of the easily distinguishable spinelliferous rim. In these cases the ilmenite of the trellis or sandwich intergrowths is not spinelliferous either. Hence a reaction between magnetite and primary ilmenite may have taken place without its detection being possible under the microscope. In addition it is possible that some ilmenite without spinel may have segregated prior to the spinelliferous ilmenite (Duchesne, 1969). The exact amount of hematite involved in the reaction cannot be determined either. The reaction may have begun at a sufficiently high temperature for the diffusion not to have produced any concentration gradient since it is possible for the gradient to appear only at a lower temperature. The rims of spinelliferous ilmenite, being situated on the external border of the magnetite grain, can be partially eliminated in the course of mineralogical separation, thus leading to under-estimation of the $\mathrm{Ti}$ content of the magnetite and hence also of the equilibrium temperature of the oxides. It appears from a detailed examination of this question (Duchesne, 1969) that a possible loss of spinelliferous ilmenite may account for the irregularities observed in the variations of the magnetite from one rock to another (cf. Fig. 5), but that it cannot entirely explain the low values of the temperature measured in the lower part of the massif $\left(T<500^{\circ}\right)$.

\section{Isolated grains: relics of the orthomagmatic stage}

As a rule, all the grains of oxides in a rock show the same type of microstructure and the same phenomena at their contact; the hematite content of ilmenite and the ilmenite content of magnetite, which the microscope reveals, are constant and in agreement with the chemical determination on separated grains. Moreover in the great majority of cases, the grains of magnetite and ilmenite are in close contact with one another. This mode of association simply results from coprecipitation of ilmenite and magnetite in the space left available after crystallization of silicate grains. Wright (1961) has drawn attention to 'granular aggregates' of ilmenite and magnetite which would result from high temperature 'exsolution' of a single phase. In the case of the rocks here studied, such a distinction appears to be quite subjective. 
Nevertheless, certain cases are exceptional: isolated grains of magnetite and ilmenite have a distinctly higher amount of $\mathrm{Ti}$ and of Hem respectively than the grains in contact. (Pl. 2, figs. C to F). These isolated grains are rare; they represent only a minute fraction of the total oxides and do not therefore influence the average content measured in the minerals after separation.

\section{EXPLANATION OF PLATES}

\section{Plate 1}

FIG. A. Cloth microtexture of the magnetite revealed by $\mathrm{HCl}$ etching. The reticulation is parallel to $\{100\}$. Al-spinel exsolutions circumscribed by box-like structures. $(\times 220$.)

FIG. B. Cloth microtexture of the magnetite (sect. // to $\{100\}$ ). $\mathrm{HCl}$ does not tarnish the magnetite component which therefore appears as small bright squares, lined up in $\{100\}$ planes. This grain was analysed by electron microprobe with a defocused beam (Table 1, anal. 53c). In the same rock (Mangerite T II) magnetite can show quite different types of microtexture (see Pl. 1, fig. D and Pl. 2, fig. H). $(\times 220$.

FIG. c. Trellis microtextured magnetite. The magnetite component, surrounded by the ilmenite lamellae, is homogeneous. $(\times 145$.)

FIG. D. Detail of a coarse trellis-microtexture grain (also called sandwich grain) of magnetite. $\mathrm{HCl}$ etching reveals a cloth microtexture in the magnetite component (lower part of the microphoto) and a progressive disappearance of the cloth towards the ilmenite lamellae (clear zone). $(\times 700$.)

FIG. E. Magnetite (section // to $\{100\}$ ). Coexistence of the cloth microtexture and of the trellis microtexture. The $\{100\}$ planes of the magnetite are emphasized by the Al-spinel lenses in N.-S. direction. A clear zone appears along the $\{111\}$ ilmenite lamellae. A rim of spinel exists at the contact with the neighbouring grain of magnetite (below, on the right). ( $\times 220$.)

FIG. F. Another example of coexistence of a trellis and a cloth. Trellis lamellae of ilmenite stand out against a cloth microtextured background of magnetite. A zoning in the transition between cloth and trellis is revealed by $\mathrm{HCl}$-etching. $(\times 220$.)

FIG. G. Contact between a primary ilmenite grain (ILM) and magnetite (MA). A rim of secondary ilmenite (C), dotted with Al-spinel microcrystals (S), develops in optical continuity with the neighbouring primary ilmenite grain. Al-spinel is arranged in a series of discontinuous fringes. Two coarser grains $(50 \mu \mathrm{m})$ occur in the ilmenite at a rather larger distance from the contact. $(\times 220$. $)$

FIG. H. Contact between grains of ilmenite and magnetite: rim of spinelliferous ilmenite bordered by a zone of homogeneous magnetite in which the cloth and the fine spinel lenses are absent. $(\times 220$.)

\section{Plate 2}

FIG. A. Another example of a rim of spinelliferous ilmenite deeply penetrating into the magnetite grain. Note the irregular distribution of spinel microcrystals and the zone of homogeneous magnetite. $(\times 220$.

FIO. B. Contact between hemo-ilmenite and magnetite. Zoning of the hemo-ilmenite demonstrated by a progressive decrease in size and number of hematite exsolutions towards the contact with a homogeneous magnetite. At the contact a rim of ilmenite very rich in spinel develops. $(x 220$.)

FIG. c. Contact between grains of hemo-ilmenite forming an isolated group (base of rhythm $V$ ): hemo-ilmenite with two generations of hematite exsolutions (approx. 18 per cent mol. Hem). $(\times 220$.)

FIG. D. Contact between grains of hemo-ilmenite and magnetite (same sample as in fig. E): hemoilmenite less rich in Hem than in fig. $c$ (approx. 13 per cent Hem) and zoned. $(\times 220$.)

FIG. E. The same assemblage of grains at lower magnification. The magnetite is homogeneous. The two oxides are distinctly interstitial. $(\times 65$.)

FIG. F. Isolated grain of magnetite (same sample as in figs. C, D, E). The magnetite contains thick lamellae of ilmenite (sandwich microtexture). The $\mathrm{TiO}_{2}$ content is of the order of 10 to 15 per cent $(\times 65$.

FIG. G. Grains of homogeneous magnetite completely surrounded by hemo-ilmenite without any zoning at the contact. Elsewhere in the same rock the hemo-ilmenite is zoned (same sample as in Pl. 2, fig. B). $(\times 220$. $)$

FIG. H. Variation in the microtextures. Two isolated grains of magnetite, $100 \mu \mathrm{m}$ apart, show different types of microtexture: on the left, a cloth-microtexture grain; on the right, a sandwich grain (with slight zoning). ( $\times 220$.) 
IRON-TITANIUM OXIDE MINERALS FROM NORWAY
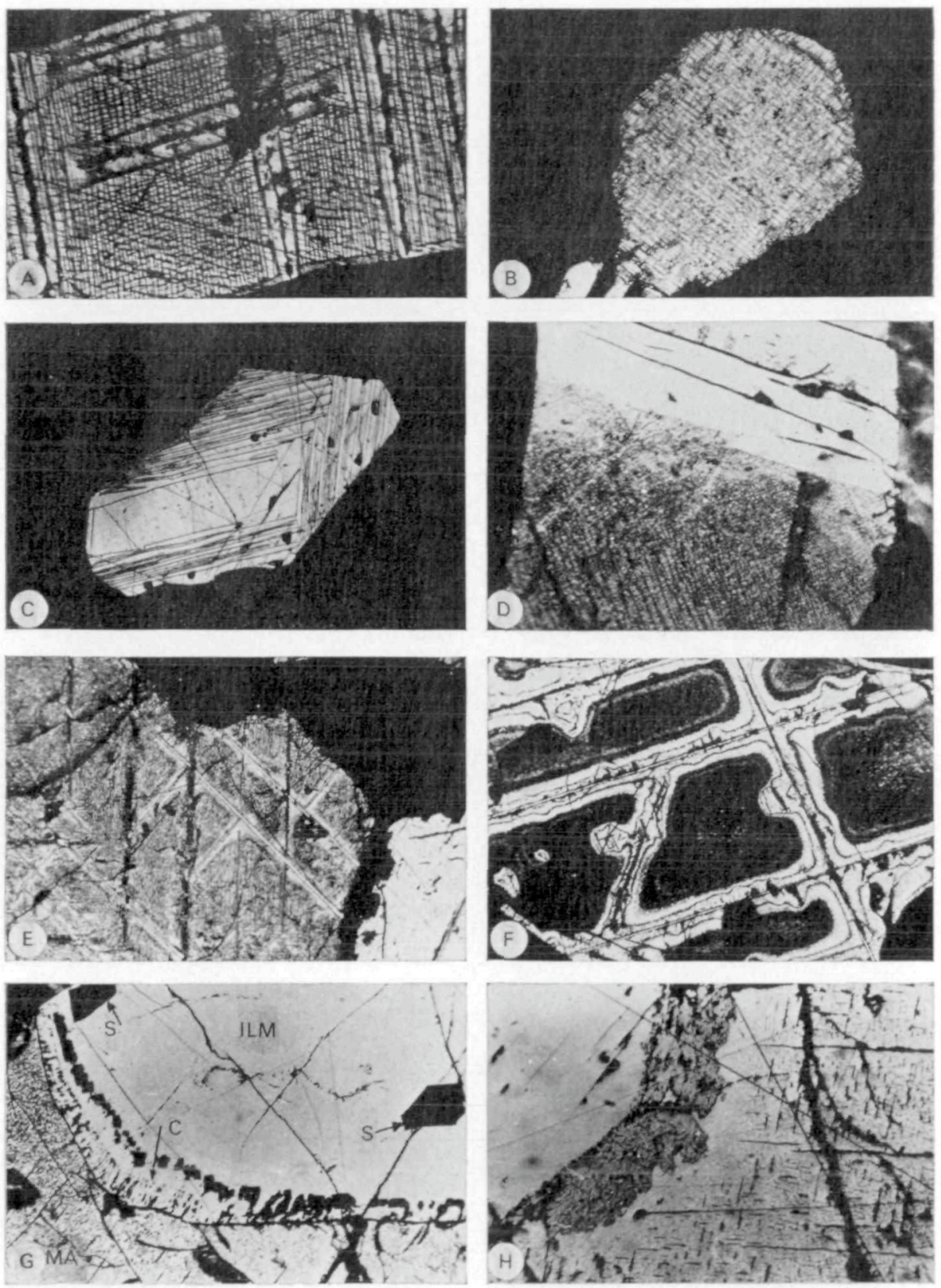

Plate 1 
J.-C. DUCHESNE
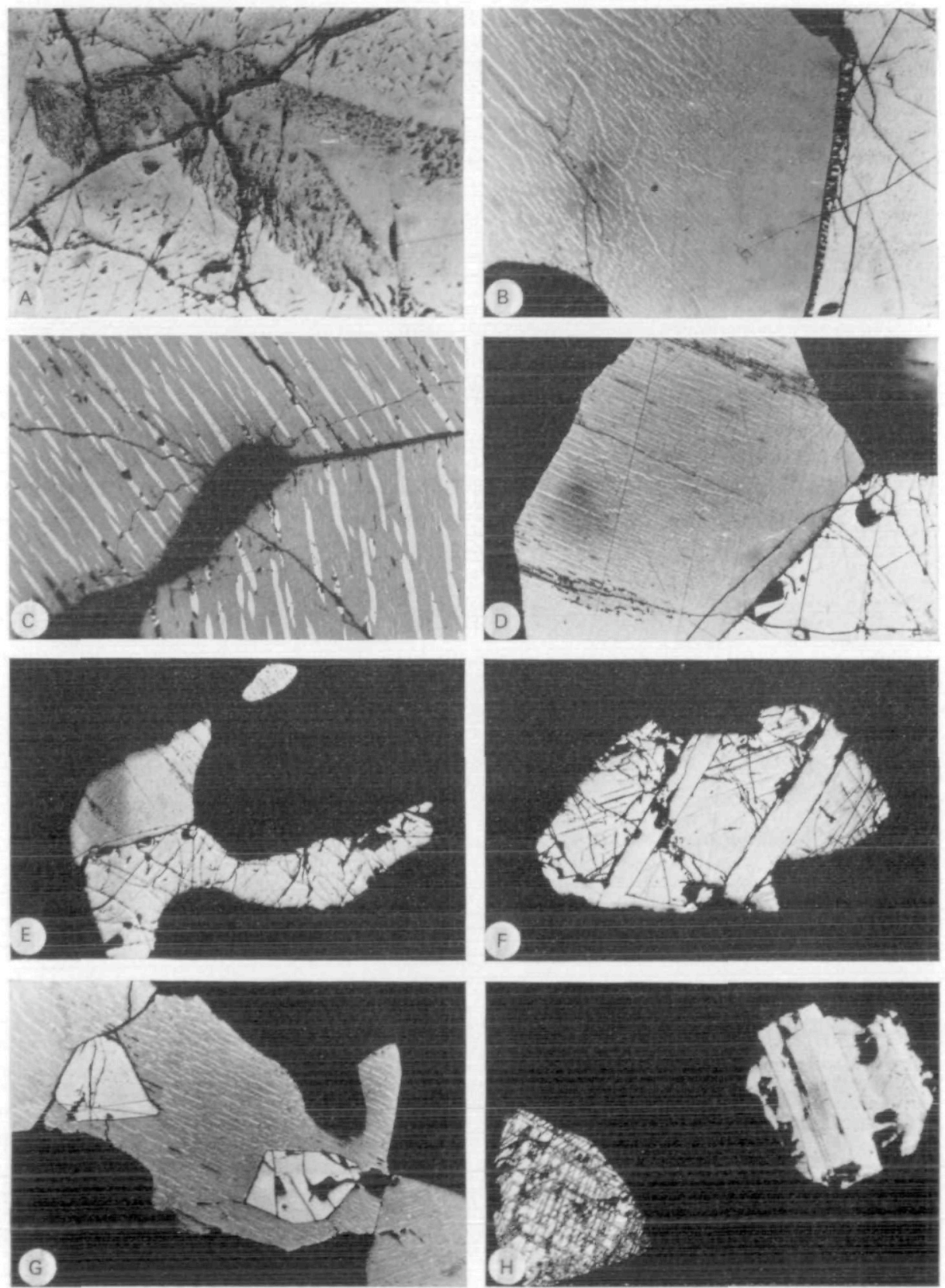

Plate 2 
These grains are interpreted as relics of the orthomagmatic stage. Indeed, owing to their isolation, grains of magnetite and ilmenite have not reacted with each other and have therefore conserved their initial composition in Hem for the ilmenite and in $\mathrm{Ti}$ for the magnetite. Isolated grains of magnetite have, however, been oxidized since no ulvöspinel is ever present.

\section{Proposed mechanism for the deuteric readjustment}

If after the orthomagmatic stage an interstitial fluid rich in volatiles such as $\mathrm{H}_{2} \mathrm{O}$ and $\mathrm{H}_{2}$ (and containing $\mathrm{O}_{2}$ by dissociation of $\mathrm{H}_{2} \mathrm{O}$ ) remains trapped in the interstices between the minerals, equilibrium between the oxides and the fluid may be maintained during slow cooling. Evidence of the existence of a fluid phase in the deuteric stage is given here by the occasional occurrence of autometamorphic biotite and amphibole.

When ilmenite and magnetite are in contact, the reaction which maintains the equilibrium can take place owing to intergranular diffusions. As diffusion becomes more and more difficult with decreasing temperature, the deuteric readjustment eventually stops at a definite temperature, which is that which may be calculated from the chemical analysis of the two coexisting grains in contact. Below that temperature the two oxides behave as closed systems. However, the magnetite continues to react with fluids to the complete oxidation of ulvöspinel. A magnetite grain, when isolated, reacts solely with interstitial fluids and thus constitutes a permanent closed system (except for oxygen).

This proposed mechanism-that composition of the two oxides may be modified in the subsolidus stage-differs from that of Buddington \& Lindsley (1964) who consider that the magnetite alone can lose Ti by external granule exsolution. Here zoning of ilmenites clearly shows that ilmenite is also involved in this readjustment process.

To summarize, it is possible to distinguish in the same rock between two types of oxide mineral assemblages: (1) The assemblage of grains in close contact, which is by far the most frequent, if not the only one present. The two oxides have undergone a deuteric readjustment and present low temperature compositions; (2) The assemblage of isolated grains considered as relics of the orthomagmatic stage.

EVOLUTION OF $T-f_{\mathrm{O}_{2}}$ CONDITIONS IN THE BJERKREM-SOGNDAL MAGMA

With the help of the isolated grains assemblage, it is possible to determine the orthomagmatic temperatures and oxygen fugacities in two important levels of the massif: the base of rhythm $\mathrm{V}$ and the mangerite phase.

At the base of rhythm $\mathrm{V}$, whereas the assemblage of grains in contact (Table 1, anal. $32 \& 32 \mathrm{a}$ ) indicates a temperature less than $500^{\circ} \mathrm{C}$ and $f_{\mathrm{O}_{2}}$ less than $10^{-22} \mathrm{~atm}$, the assemblage of isolated grains leads to $T$ between 900 and $975^{\circ} \mathrm{C}$ and $f_{\mathrm{O}}$ of the order of $10^{-11} \mathrm{~atm} .{ }^{1}$ Isolated grains of magnetite have an amount

${ }^{1}$ In this paper $T$ and $f_{0}$, are given regardless of the systematic experimental uncertainty of $\pm 50^{\circ} \mathrm{C}$ $\pm 1 \cdot 0 \log f_{0}$, claimed by Buddington \& Lindsley. 
of 10-15 per cent $\mathrm{TiO}_{2}$, equivalent to $\mathrm{Usp}_{33-40}$. The composition of isolated hemoilmenite is approximately $\mathrm{Hem}_{18}$. In these rocks (Pl. 2, figs. E to J) the chemical composition of isolated grains is estimated under the microscope (Duchesne, $1970 \mathrm{~b}$ ). Use is made in hemo-ilmenite of a relationship put forward by Duchesne $(1970 b)$ between bulk chemical composition and microtexture (size and density of distribution of hematite lenses). Since the isolated magnetite grains show a coarse trellis intergrowth ('sandwich' gain), the determination of the volume content of ilmenite is carried out by measuring the areal proportion of the ilmenite lamellae in several suitably oriented sections.

In the mangerite phase temperatures measured with the grains-in-contact assemblage (Table 1 , anals. 52, 52a; 53, 53a, b; 54, 54a; 55, 55a, b) lie about $650^{\circ} \mathrm{C}$. The occurrence of mesoperthite $\left(\mathrm{Or}_{45} \mathrm{Ab}_{48} \mathrm{An}_{7}\right)$ indicates a crystallization temperature of at least $660^{\circ} \mathrm{C}$ (Bowen \& Tuttle, 1950). The quartz-mangerites contain the fayalite $\left(\mathrm{Fo}_{6}\right)+\mathrm{Ti}$-rich magnetite +quartz assemblage. It is therefor conceivable that the initial $T-f_{\mathrm{O}}$, conditions approximately fall on the FMQ curve (Eugster \& Wones, 1962). Isolated cloth-microtexture grains of magnetite have an amount of $\mathrm{Ti}$ (determined with the electron-probe analyser using a defocused beam; Table 1, anal. 53c) equivalent to $\mathrm{Usp}_{60}$. An approximative temperature of $750-800^{\circ} \mathrm{C}$ and an oxygen fugacity of approximately $10^{-16} \mathrm{~atm}$ (i.e. slightly below the FMQ curve at $750-800^{\circ} \mathrm{C}$ ) seem plausible. ${ }^{1}$ These imply $\mathrm{Hem}_{3-4}$ for the initial composition of the ilmenite.

Consequently during the magmatic differentiation, which has produced the series of rocks starting from the base of rhythm $V$ to the top of the massif, it can be assessed that the $f_{\mathrm{o}}$ of the magma has decreased from values slightly above the $\mathrm{Ni}-\mathrm{NiO}$ buffer to values slightly below the FMQ buffer (Fig. 7). Thus, the magma became more and more reducing.

Between these two levels, and below the base of rhythm $\mathrm{V}$, it is not possible to obtain further details of the initial $f_{\mathrm{O}_{2}}-T$ conditions. Isolated grains are rare or absent, their composition is difficult to determine with accuracy. Moreover some rocks are devoid of magnetite. Conversely, starting from the grains-incontact assemblage, the initial conditions cannot be assessed since the deuteric evolution of $f_{\mathrm{O}}$, with $T$ is not known. In the $f_{\mathrm{O}}-T$ plane, the function $\mathrm{F}$ relating $T$ and $f_{\mathrm{O}_{3}}$ in the deuteric stage must be situated between the two isocompositional curves which intersect at the point representing the orthomagmatic $T-f_{\mathrm{O}_{2}}$ conditions (Fig. 7). This is indeed the only way to interpret the observed trends in the deuteric readjustment. Nevertheless the position and shape of the function $F$ inside this area are not known. Neither is it impossible that, at different points in the same rock, the function may be different: e.g. (1) the occasional absence of zoning of the hemo-ilmenite (Pl. 2, fig. G) may be explained if the function $\mathrm{F}$ in $f_{\mathrm{o}}=\mathrm{F}(T)$ had been superimposed on the isocompositional curve of the ilmenite at this particular point of the rock; (2) it can be seen from Pl. 2, fig. $\mathbf{H}$

1 A further confirmation has been provided by Dr. D. H. Lindsley (personal communication) who calculated that the $f_{\mathrm{O}_{2}}$ is $\downarrow$ to 1 order of magnitude below that of the FMQ buffer. 
that very different types of microtextures can occur in two neighbouring isolated grains. The latter implies a supersolvus oxidation for the sandwich grain and a subsolvus oxidation for the cloth microtextured grain. Differential diffusions could then give rise, at a given subsolidus temperature, to different values of $f_{\mathrm{O}_{\mathbf{z}}}$ at different points of the same rock.

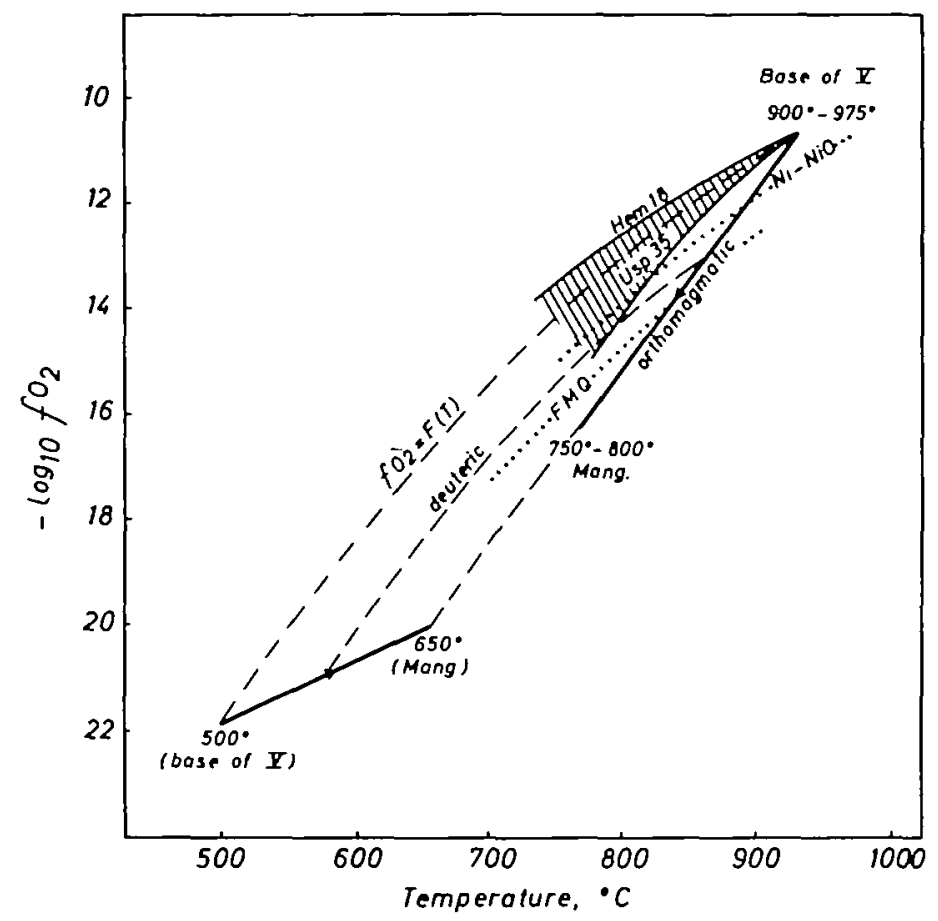

FIG. 7. Schematic reconstitution of the evolution of $f_{0,}-T$ orthomagmatic conditions during fractional crystallization from the base of rhythm $V$ up to the top of the massif. In the deuteric stage, the oxygen fugacities presumably vary as indicated by parallel dashed curves. The curve $f_{\mathrm{O}_{2}}=\mathrm{F}(T)$ relative to the rocks of the base of rhythm $\mathrm{V}$, as a particular example, must necessarily be situated inside the cross-hatched area (see text). The deuteric readjustment eventually leads to the observed temperatures and oxygen fugacities. Buffer curves from Eugster \& Wones (1962).

Nevertheless, it can be observed that in passing from the base of rhythm $\mathrm{V}$ to the summit of the massif, there is a progressive change from the Ti-poor magnetite + hemo-ilmenite assemblage to the Ti-rich magnetite +homogeneous ilmenite assemblage. Consequently it can be inferred that the diverse curves $f_{\mathrm{O}_{2}}=\mathrm{F}(T)$ which express the average evolution of $f_{\mathrm{O}}$, with $T$ at the deuteric stage have roughly parallel shapes. As shown on Fig. 7, the evolution of the low temperature association with the stratigraphic sequence tends to reflect a homologous orthomagmatic evolution.

A similar mechanism may be invoked for rhythms III and IV, and thus the initial $f_{\mathrm{O}_{2}}$ would have decreased from the base to the summit of the rhythms. 
Consequently, the sudden changes in the oxide assemblage at the base of the rhythms are the result of a sudden increase in the oxygen fugacity of the magma. Assuming that the magma remained at nearly the same temperature in passing from the top of a rhythm to the base of the following one and that the system crystals plus liquid remained closed (except for gases), the sudden increase of the oxygen fugacity must be due to a differential diffusion of hydrogen towards the external envelope. This phenomenon, owing to its sudden and repeated character, remains difficult to understand.

A more plausible explanation of the rhythmic structure and related oxygen fugacity changes can be given if it is considered that the chemical composition and the temperature of the magma have changed at the base of each rhythm. Evidence in favour of the last process is derived from the study of the minor elements in the oxides.

\section{MINOR ELEMENTS IN THE OXIDES}

It is probable that the deuteric readjustment may modify the initial contents of minor elements. In order to judge the importance of this modification the following simplified model can be used. A magnetite grain is impoverished in Ti during the deuteric readjustment because some secondary ilmenite has been segregated to constitute an external rim. Moreover, through partial oxidation, the $\mathrm{Fe}^{3+} / \mathrm{Fe}^{2+}$ ratio in the magnetite increases. Now there are two possibilities: (i) the segregation of ilmenite does not change the initial content of a particular element in the magnetite if the magnetite and the secondary ilmenite have the same composition with regard to that element; (ii) the segregation can increase (or decrease) the initial content in the magnetite if the secondary ilmenite has a lower (or higher) content than the magnetite. As V, Zn, and Ga are always distinctly more abundant in magnetite than in ilmenite, it can be considered that the deuteric readjustment increases the initial content of these elements in the magnetite. In the extreme case, in which the secondary ilmenite is devoid of these elements, it is possible to calculate a maximum enrichment factor of the initial content in the magnetite, provided that the major element contents before and after the deuteric readjustment are known. This can be done in the rocks at the base of rhythm $\mathrm{V}$ and in the mangeritic phase (Table 2) in which initial compositions of the magnetites were assessed. In Table 2 the minimum initial content of certain trace elements is calculated by dividing the measured content by the maximum enrichment factor. The maximum content is the measured content itself (no influence of deuteric readjustment). This procedure clearly shows that, in the course of differentiation giving rise to the rocks from the base of rhythm $\mathrm{V}$ up to the summit, the ratios $\mathrm{Ga} / \mathrm{Fe}^{3+}, \mathrm{Zn} / \mathrm{Fe}^{2+}$ increase and $\mathrm{V} / \mathrm{Fe}^{3+}$ decreases. A similar trend for $\mathrm{V}$ in oxides is reported by Vincent \& Phillips (1954), Lister (1966), and Anderson (1966). The impoverishment of $\mathrm{V}$ in the successive residual liquids is the established outcome of magmatic 
differentiation. The behaviour of $\mathrm{Ga}$ in the magnetites is very similar to that found in the Skaergaard magnetites by Vincent \& Phillips (1954).

As for $\mathrm{Mn}$, the proposed calculation is not valid. Since $\mathrm{Mn}$ is preferentially enriched in the ilmenite, the initial content decreases through the deuteric readjustment by an amount which is difficult to calculate because the Mn content in the segregated ilmenite is unknown. Nevertheless, in the ilmenites of the upper part of the massif (mangeritic phase), the Mn content distinctly increases,

TABLE 2

Part 1

\begin{tabular}{|c|c|c|c|c|c|}
\hline \multirow[b]{2}{*}{ Rocks } & \multicolumn{3}{|c|}{ Initial composition } & \multirow{2}{*}{$\begin{array}{c}\text { Composition } \\
\text { after } \\
\text { readjustment }\end{array}$} & \multirow{2}{*}{$\begin{array}{c}\text { Maximum } \\
\text { enrichment } \\
\text { factor }\end{array}$} \\
\hline & & $\mathrm{Fe}^{2+}$ & $\mathrm{Fe}^{\mathrm{t+}}$ & & \\
\hline $\begin{array}{l}\text { Base of } \mathrm{V} \\
\text { Mang. phase }\end{array}$ & $\begin{array}{l}\mathbf{M t}_{\mathbf{s}} U_{s p_{25}} \\
\mathrm{Mt}_{\mathrm{s} 0} U_{s p_{s s}}\end{array}$ & $\begin{array}{l}31 \cdot 6 \\
24 \cdot 5\end{array}$ & $\begin{array}{l}33 \cdot 0 \\
36 \cdot 8\end{array}$ & $\begin{array}{l}\mathrm{Mt}_{07} \mathrm{Usp}_{2} \\
\mathrm{Mt}_{65} \mathrm{Usp}_{25}\end{array}$ & $\begin{array}{l}1 \cdot 27 \\
1 \cdot 14\end{array}$ \\
\hline
\end{tabular}

Part 2

\begin{tabular}{|c|c|c|c|}
\hline & & $\begin{array}{c}\text { Base of Rhythm } V \\
\text { (Table 1, anal. } \\
\text { 32a) }\end{array}$ & $\begin{array}{c}\text { Mangeritic phase } \\
\text { (Table } 1, \text { anals. } \\
52 a, 53 a, 54 a, \& 55 a)\end{array}$ \\
\hline $\begin{array}{l}\text { Measured content or } \\
\text { maximum initial } \\
\text { content (per cent) }\end{array}$ & $\begin{array}{l}\mathrm{V}^{3+} \\
\mathrm{Ga}^{2+} \\
\mathrm{Zn}^{2+}\end{array}$ & $\begin{array}{l}0.61 \\
0.013 \\
0.044\end{array}$ & $\begin{array}{l}0.041 \\
0 \cdot 034 \\
0 \cdot 16\end{array}$ \\
\hline $\begin{array}{l}\text { Minimum initial } \\
\text { content (per cent) }\end{array}$ & $\begin{array}{l}\mathrm{V}^{3+} \\
\mathrm{Ga}^{3+} \\
\mathrm{Zn}^{2+}\end{array}$ & $\begin{array}{l}0.48 \\
0.010 \\
0.035\end{array}$ & $\begin{array}{l}0 \cdot 036 \\
0 \cdot 030 \\
0 \cdot 14\end{array}$ \\
\hline $\begin{array}{l}\text { Initial ratio } \\
\qquad\left(\times 10^{-2}\right)\end{array}$ & $\begin{array}{l}\mathrm{V}^{2+} / \mathrm{Fe}^{2+} \\
\mathrm{Ga}^{2+} / \mathrm{Fe}^{3+} \\
\mathrm{Zn}^{2+} / \mathrm{Fe}^{2+}\end{array}$ & $\begin{array}{l}\text { from } 19 \text { to } 15 \\
\text { from } 0.32 \text { to } 0.41 \\
\text { from } 1 \cdot 1 \text { to } 1 \cdot 3\end{array}$ & $\begin{array}{l}\text { from } 1 \cdot 5 \text { to } 1 \cdot 7 \\
\text { from } 1 \cdot 2 \text { to } 1 \cdot 4 \\
\text { from } 3 \cdot 8 \text { to } 4 \cdot 3\end{array}$ \\
\hline
\end{tabular}

whereas the $\mathrm{Fe}^{2+}$ remain nearly constant (cf. Fig. 4). It can then be considered that the ratio $\mathrm{Mn}^{2+} / \mathrm{Fe}^{2+}$ increases in this stage of differentiation, such a conclusion being in close agreement with the classical behaviour of $\mathrm{Mn}$ in magmas. Buddington (1964) and Buddington \& Lindsley (1964) have suggested that the distribution of $\mathrm{Mn}$ between magnetite and ilmenite is controlled by temperature. This suggestion is confirmed here for the temperature at the end of the deuteric readjustment (i.e. the measured temperature) (Fig. 8). Taking into account the results of Anderson (1968), it appears that the variation of the distribution factor is not linear but exponential.

The sudden variations in contents of $\mathrm{Mn}, \mathrm{V}$, and $\mathrm{Zn}$ at the base of the rhythms (Figs. 4 and 5) cannot be used to show a possible variation of chemical composition of the magma at the base of the rhythms. Indeed the initial contents of these elements have been modified by deuteric phenomena, the amplitude of 
which is impossible to assess in that part of the massif. However, these considerations do not apply to the variations of $\mathrm{Cr}, \mathrm{Ni}$, and $\mathrm{Co}$. It is observed that, in addition to the decrease in amounts on the scale of the massif, the variation of $\mathrm{Cr}$ and of the ratio $\mathrm{Ni} / \mathrm{Co}$ in the two oxides is closely related to the rhythmic structure. Since these variations are mostly observed in rocks in which ilmenite is the only oxide present (rhythms I, II, bases of III and IV), and in which consequently no deuteric readjustment has occurred, it can be concluded that

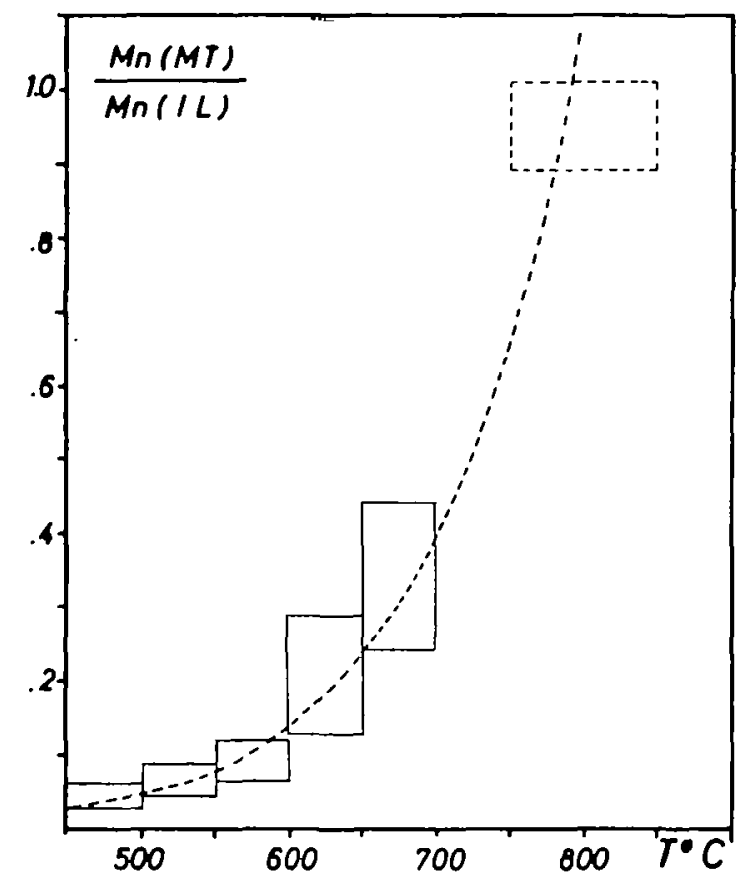

FIG. 8. Correlation between the distribution of $\mathrm{Mn}$ between ilmenite and magnetite and the equilibrium temperature of the oxide minerals in the Bjerkrem-Sogndal massif and in the Rogaland ores (full-line rectangles). Data from Anderson (1968) for the La Blache Lake deposit are also plotted (dotted rectangle: average of 5 samples). The correlation seems to be exponential, as suggested by the dashed curve.

the observed variations are inherited from the orthomagmatic stage and are due to similar variations in the magma.

Trace element analysis of a few rock samples have further confirmed this conclusion (Duchesne, 1969). The decrease in the amount of $\mathrm{Cr}$ and of the ratio $\mathrm{Ni} / \mathrm{Co}$ with the degree of differentiation is well established in all the magmatic suites (Nockolds \& Allen, 1953, 1954, 1956). A similar trend is also observed for $\mathrm{Cr}$ in oxides (Wager \& Mitchell, 1951; Vincent \& Phillips, 1954; Carstens, 1957; Papezik, 1965; Lister, 1966).

Therefore, the changes in the chemical composition of the magma at the base of the rhythms are recurrences of the basic character of the magma. 


\section{CONCLUSIONS}

Whatever the mechanism determining the recurrences, it is possible to leave aside the recurrent character of the Bjerkrem-Sogndal differentiation, and to reconstitute the ideal lithological sequence characteristic of the plagioclasic magma. The leuconoritic phase can be divided into three main stages which succeed each other through decreasing temperature: stage 1: formation of anorthosites followed by leuconorites in which the only oxide is hemo-ilmenite; stage 2: leuconorites followed by norites in which hemo-ilmenite coexists with titaniferous magnetite; stage 3: 1 clinopyroxene-bearing norites containing the two oxides. This last stage is followed by the monzonoritic and mangeritic phases. From stage 2 to the end the ilmenite grows poorer in hematite while the magnetite is enriched in $\mathrm{Ti}$.

Taking into account the results at the base of rhythm $\mathrm{V}$, the temperature of the magma at the beginning of the second stage is in the order of $900-975^{\circ} \mathrm{C}$ $\pm 50^{\circ} \mathrm{C}$ and the oxygen fugacity in the order of $10^{-11 \pm 1}$ atm. The reducing character of the magma increases during fractional crystallization. $\mathrm{Cr}$ is enriched in stage 1 . Ni exceeds Co in stage 1 , and further on the relationship reverses itself. The ratio $\mathrm{V} / \mathrm{Fe}^{3+}$ decreases, the ratio $\mathrm{Mn} / \mathrm{Fe}^{2+}, \mathrm{Ga} / \mathrm{Fe}^{3+}$, and $\mathrm{Zn} / \mathrm{Fe}^{2+}$ increase. Such behaviour is typical of other magma suites. A magnesian olivine can crystallize in the first stage of the evolution.

By analogy with the melting relations in the pure $\mathrm{FeO}-\mathrm{Fe}_{2} \mathrm{O}_{3}-\mathrm{TiO}_{2}$ system (Taylor, 1963), it can be inferred that a cotectic line separates the ilmenite and magnetite fields. In stage 1 of the idealized lithological sequence of BjerkremSogndal the composition of the liquid lies in the ilmenite field. With decrease of temperature, the cotectic line is reached at stage 2 of the evolution; magnetite appears and coprecipitates with ilmenite. Both oxides with continued crystallization become richer in the lower melting-point end member, i.e. $\mathrm{FeTiO}_{3}$ for the ilmenite and $\mathrm{Fe}_{2} \mathrm{TiO}_{4}$ for the magnetite. Experimental data and natural evolution are thus shown to be in complete agreement.

The Buddington \& Lindsley geothermometer does not show the orthomagmatic temperature but instead the temperature at the end of the deuteric readjustment, which is lower. When used on the relict assemblages, it yields plausible values for the orthomagmatic stage. The deuteric evolution is difficult to reconstitute quantitatively. In certain cases, it appears to be different from point to point in the same rock. Deuteric oxidation of the ulvöspinel contained in the magnetite can modify the $\mathrm{Fe}^{3+} / \mathrm{Fe}^{2+}$ ratio in the whole rock, particularly in Ti-rich magnetite bearing rocks. This ratio must therefore be used with caution as a petrological parameter.

Evidence of chemical recurrences related to the rhythmic structure raises the problem of the genesis of the rhythms. On the basis of the occurrence of anorthositic inclusions which have their source in the neighbouring EgersundOgna anorthositic massif, the present author (Duchesne, 1970a) has shown that 
a flow of magma carrying these xenoliths had overlapped the rocks of rhythm I when these were already completely consolidated. It is therefore strongly suggested that widespread lateral flow movements of magma have taken place in the lopolith during differentiation. These migrations are likely to be a consequence of the synkinematic character of the consolidation of the massif.

To explain the chemical recurrences brought about by these movements, one can postulate variable differentiation rates from one place to another in the lopolith, and consider that the rhythms are due to internal processes in the massif. Nevertheless, the present author inclines to support the view that the rhythms are due to external processes: intermittent supplies of undifferentiated magma. After the initial act of intrusion, fresh magma would flow into the magma chamber at regular intervals and mix with progressively lower temperature residual magma. These influxes would take the same path as the initial intrusion, which is a surface near to that which separates the Egersund-Ogna massif and its sedimentogenous gneiss cover, as put forward by Michot (1960b). This accounts for the source of the xenoliths present at the base of rhythm II. The leuconoritic phase would then appear as the 'integration phase' (Wager \& Brown, 1968) of the Bjerkrem-Sogndal's crystallization history.

\section{ACKNOWLEDGEMENTS}

The author is greatly indebted to Professor P. Michot for suggesting this study which was carried out under his supervision. The author is also indebted to Dr. P. Herman for his helpful guidance in the chemical methods. Thanks are due to Professor P. Bartholomé for stimulating discussions, and to Professor A. F. Buddington for encouragement. Dr. S. R. Nockolds has greatly assisted in preparing this article. Dr. N. F. M. Henry has revised the English. Dr. D. H. Lindsley and Professor E. A. Vincent have also read the manuscript, the final form of which has greatly benefited from their remarks.

This work was supported in part by the 'Fonds de la Recherche Fondamentale Collective' (Belgium). A grant from the Royal Society supported a period of work in the Department of Mineralogy and Petrology, University of Cambridge.

\section{REFERENCES}

ANDERSON, A. T., 1968. Oxidation of the La Blache Lake titaniferous magnetite deposit. Quebec. J. Geol. 76, 528-47.

- 1966. Mineralogy of the Labrieville anorthosite. Quebec. Am. Miner. 51, 1671-1711.

Bowen, N. L., \& TuTtLe, O. F., 1950. The system NaAISi, $\mathrm{O}_{8}-\mathrm{KAlSi}_{3} \mathrm{O}_{8}-\mathrm{H}_{2} \mathrm{O}$. J. Geol. 58, 489-511. Buddington, A. F., 1964. Distribution of $\mathrm{MnO}$ between coexisting ilmenite and magnetite. In Advancing Frontiers in Geology and Geophysics, Osmania University Press, Hyderabad, India, $233-48$.

— FAHEY, J., \& Vlisidis, A., 1955. Thermometric and petrogenetic significance of titaniferous magnetite. Am. J. Sci. 253, 497-532.

_ \& LindSLey, D. H., 1964. Iron-titanium oxide minerals and synthetic equivalents. J. Petrology, $5,310-57$.

Carmichael, C. M., 1961. The magnetic properties of ilmenite-hematite crystal. Proc. R. Soc. London, Ser. A, 263, 508-30. 
Carstens, H., 1957. Investigation of titaniferous iron ore deposits. Kgl. Norske Videnskab. Selskabs, Skrifter, Pt. I, 3, 3-67; Pt. II, 4, 3-24.

Duchesne, J. C., 1966. Séparation rapide des minéraux des roches. Ann. Soc. Géol. Belg. 87, $347-56$.

- 1969. Les minéraux noirs dans le massif magmatique stratiforme de Bjerkrem-Sogndal (Rogaland) et leur évolution dans la différenciation. Unpublished Dr. Sc. thesis, Liège University.

- 1970a. Sur la provenance de xénolithes d'anorthosites dans le massif de Bjerkrem-Sogndal (Rogaland méridional-Norvège). Ann. Soc. Géol. Belg. 93, 527-44.

- 1970b. Microtextures of Fe-Ti oxides minerals in the South-Rogaland anorthositic complex (Norway). Ibid. 93, 523-6.

Eugster, H. P., \& WonES, D. R., 1962. Stability relations of the ferruginous biotite, annite. $J$. Petrology, 3, 82-125.

LindSLEY, D. H., 1962. Investigations in the system FeO-Fe $\mathrm{O}_{2}-\mathrm{TiO}_{2}$. Yb. Carnegie Instn. Wash. 61, $100-6$.

1963. Equilibrium relations of coexisting pairs of Fe-Ti oxides. Ibid. 62, 60-6.

Lister, G. F., 1966. The composition and origin of selected iron-titanium deposits. Econ. Geol. 61, 275-310.

Michor, P., 1951. Essai sur la geologie de la catazone. Bull. Acad. roy. Belg., Cl. des Sciences, 5th série, 37, 260-76.

- 1955. Anorthosites et anorthosites. Ibid. 41, 275-94.

- 1960a. La géologie de la catazone: le problème des anorthosites, Ja palingenèse basique et la tectonique catazonale dans le Rogaland méridional (Norvège méridionale). Norges Geol. Unders. $212 \mathrm{~g}, 1-54$.

— 1960b. Le probleme des intrusions marginales. Geol. Rundschau 50, 94-105.

1964. Le magma plagioclasique. Ibid. 54, 956-76.

- 1970. The geological environment of the anorthosites in South Rogaland (Norway) in 'The origin of anorthosite and related rocks'. Y. W. Isachsen, ed. N.Y. State Mus. Sci. Serv. Mem. 18, 411-23.

Nockolds, S. R., \& Allen, R., 1953, 1954, 1956. The geochemistry of some igneous rocks series. Geochim. cosmochim. Acta 4, 105-42; 5, 245-85; 9, 34-7.

PaPezK, V. S., 1965. Geochemistry of some Canadian anorthosites. Ibid. 29, 673-709.

Rambohr, P., 1953. Ulvöspinel and its significance in titaniferous iron ores. Econ. Geol. 48, 677-88.

SWEatman, T. R., \& LoNG, J. V. P., 1969. Quantitative electron-probe microanalysis of rock-forming minerals. J. Petrology, 10, 332-79.

TAYLOR, R. W., 1963. Liquidus temperatures in the system FeO-Fe, $\mathrm{O}_{2}-\mathrm{FeTiO}_{3}$. J. Am. Ceram. Soc., 46, 276-9.

VINCENT, E. A., 1960. Ulvöspinel in the Skaergaard intrusion, Greenland. N. Jb. Miner. Abh., 94, 993-1016.

__ \& Phillips, R., 1954. Iron-titanium oxide minerals in layered gabbro of the Skaergaard intrusion East Greenland. Part 1. Chemistry and ore-microscopy. Geochim. cosmochim. Acta, 6 1-26.

— Wright, J. B., Chevallier, R., \& Mathieu, S., 1957. Heating experiments on some natural titaniferous magnetites. Mineralog. Mag. 21, 624-55.

WAGER, L. R., \& MrtChell, R. L., 1951. The distribution of trace elements during strong fractionation of basic magma-a further study of the Skaergaard intrusion-East Greenland. Geochim. cosmochim. Acta 1, 129-208.

\& Brown, G. M., 1968. Layered igneous rocks. London: Oliver \& Boyd.

Wright, J. B., 1961. Solid-solution relationships in some titaniferous iron oxide ores of basic igneous rocks. Mineralog. $M a g$ 32, 778-89. 